\title{
MENCEGAH PERILAKU BULLYING DI SEKOLAH MENENGAH
}

\author{
Sudjiwanati \\ Fakultas Psikologi Universitas Wisnuwardhana Malang \\ sudjiwanati@yahoo.com
}

\begin{abstract}
Adolescence is a period of physical growth and mental emotional development, which still requires guidance to shape personality, but during its development there are some adolescents who experience obstacles during development. Primarily during the early development period, namely in the junior high school period, there were several adolescents who experienced developmental obstacles from the impact of bullying at school. The purpose of community service is to prevent bullying behavior so that children grow and develop according to their personality development period, which can prevent them from becoming bullies and victims of bullying at school. The implementation method applied is the preparation stage, the psychological examination stage, namely BAUM, DAM, HTP and Wartegg, the counseling stage, the psychological examination evaluation stage, the work results and reporting. The result of this service is a guidebook for the prevention of handling perpetrators of bullying behavior and victims of bullying in schools that can be used by teachers in junior high schools, in overcoming the issue of bullying in schools.
\end{abstract}

Keywords: Behavior, Bullying, Preventive

\section{PENDAHULUAN}

Sekolah Menengah Pertama merupakan tempat anak remaja memulai melatih kehidupan secara sosial di lingkungan yang cenderung kepada tingkat remaja seutuhnya. Namun banyak ditemukan kasus anak remaja khususnya di sekolah adanya peristiwa bullying terhadap temannya yang terjadi di dalam kelas atau terjadi di luar kelas, yang memerlukan pencegahan.

Banyak temuan pula yang di temukan dari beberapa sekolah yang menunjukkan adanya beberapa kasus yang sama yaitu peristiwa bullying yang terjadi di dalam klas dan di luar kelas dan yang dapat berlanjut di luar jam sekolah. Kasus banyakkanya bullying secepatnya perlu diangkat ke permukaan pada suatu kegiatan pengabdian masyarakat di sekolah. Remaja pada masa di Sekolah Menengah Pertama merupakan masa badai dan stres dalam menghadapi kehidupan sehari-hari. Berbagai cara yang dapat digunakan untuk memberikan penanganan bullying tetapi berbeda dengan penanganan bullying di sekolah. Oleh sebab itu perlu mencari cara yag tepat dalam menangani kasus yang berada di sekolah agar menghasilkan suatu cara dengan bentuk buku panduan yang dapat digunakan oleh guru. Kiranya perlu dicari cara yang harus ditemukan dari kegiatan pengabdian pada pencegahan perilaku bullying di sekolah dalam bentuk buku panduan yang dapat digunakan untuk penanganan terhadap pelaku perilaku bullying dan korban bullying khusus di sekolah.

Definisi bullying menurut Olweus adalah ketika seorang siswa berulang kali terkena tindakan negatif oleh satu atau lebih siswa lainnya baik berupa tindakan fisik seperti kontak fisik, pelecehan verbal atau membuat mimik wajah dan gerak tubuh kasar. Menyebarkan desas-desus tentang korban dari suatu kelompok juga bentuk umum dari bullying (Omoteso, 2010).

Menurut Curtner dan Smith (2000), karakteristik hubungan yang terjadi antara orang tua dan anak merupakan mekanisme utama pelaku bullying dalam bentuk perilaku agresif dan pasif. Orang tua dalam mendidik anak akan menggunakan pola asuh yang berbedabeda yang dapat mempengaruhi perkembangan anak. Pola asuh orang tua yang menggunakan kekerasan dapat menyebabkan anak melakukan kekerasan pada orang lain karena anak mencontoh tindakan yang dilakukan orang tuanya. Hasil penelitian ini menunjukkan sebagai responden (pelaku bullying) sering mendengar kata-kata kasar 
dalam keluarganya $(45,7 \%)$, sebagian besar $(36,2 \%)$ keluarga menerapkan pola asuh otoriter yang ditunjukkan dengan perilaku kekerasan seperti memukul bila bersalah, sering memberi hukuman yang tidak mendidik, hal ini akan mendorong anak untuk melakukan hal yang sama kepada teman-temannya sebagai pembenaran yang dilakukan. Pola asuh otoriter akan melahirkan perilaku agresif pada anak (Brookmen et al., 2010; Sari, 2017).

Sekolah Menengah Pertama merupakan tempat anak remaja awal belajar bersosialisasi pada tingkat yang lebih tinggi perkembangannya. Pada beberapa sekolah tentunya menjadi hubungan sosial anak dalam mengekpresikan kebahagiannya dan ada yang dalam bentuk kemarahannya dengan perilaku bullying pada temannya sebagai pelaku, dan temannya atau orang lain yang menjadi korban. Setyawan (2014), menunjukkan kasus khususnya dikalangan pelajar menunjukkan tren yang terus meningkat. Menurut data dari Komisi Perlindungan Anak Indonesia dari tahun 2011 sampai tahun 2014 terjadi 369 pengaduan terkait kasus bullying atau 25\% dari total kasus yang diterima oleh Komisi Perlindungan Anak Indonesia mengalahkan tawuran pelajar, diskriminasi pendidikan dan pungutan liar.

Wiyani (2012) menyatakan bahwa di Indonesia sendiri sudah ada survei yang dilakukan oleh, Yayasan Semai Jiwa Amini pada tahun 2008, dari 1.233 orang siswa Sekolah Dasar, Sekolah Menengah Pertama dan Sekolah Menengah Atas di tiga kota besar di Indonesia yaitu, Jakarta, Surabaya, dan Jogyakarta terjadi kekerasan antar siswa di Sekolah Menengah Pertama secara berurutan terjadi di Jogyakarta (77,5\%), Jakarta $(61,6 \%)$ dan Surabaya $(59,8 \%)$. Kekerasan di tingkat SMA terbanyak terjadi di Jakarta $(72,7 \%)$, Surabaya $(67,2 \%)$ dan terakhir Yogyakarta (63,8\%). Megan Mier Foundation (2014), data yang diperoleh dari National Center for Educational Statistic of America pada tahun 2013, didapatkan bahwa 27,8\% siswa melakukan bullying selama di sekolah (Fithria \& Aulia, 2016; Wiyani, 2012).

Isu-isu yang terkait dengan masalah Bullying merupakan suatu perilaku berulang yang dilakukan secara agresif dan sengaja baik secara fisik maupun verbal terhadap orang lain yang lebih lemah dan tidak mampu memberikan perlawanan. Kasus bullying dapat terjadi pada siapa saja baik pada anak-anak, remaja, bahkan pada orang dewasa. Bullying yang terjadi pada remaja utamanya pada masa perkembangan remaja awal khususnya di Sekolah Menengah Pertama pada masa kini terdapat banyak kasus mulai dari bullying menggunakan bahasa yang menyudutkan lawan bicara, kata-kata yang kasar sampai pada perilaku penganiayaan dan pembunuhan terhadap sesama siswa di sekolah. Perilaku bullying yang terjadi di sekolah tidak hanya semata karena faktor pergaulan anak dengan lingkungannya, tetapi ada banyak faktor yang juga mempengaruhi terjadinya bullying di sekolah seperti kontrol guru di sekolah, peran keluarga, tingkat pengetahuan tentang dampak bullying, faktor internal anak, budaya keluarga. Menurut Kertamuda (2009) keluarga di Indonesia sangat kuat dipengaruhi oleh suatu sistem, baik itu kekerabatan, budaya, norma dan adat-istiadat yang berlaku, dan juga sistem nilai yang ada. Bentuk keluarga juga erat kaitannya dengan semakin kompleksnya kehidupan saat ini yang ditimbulkan oleh status sosial dan ekonomi dan juga dinamika yang terjadi dalam keluarga Indonesia (Kertamuda, 2009; Ulfiah, 2016).

Perilaku bullying yang terjadi di kalangan siswa dapat terjadi sebagai bagian adaptasi dengan lingkungannya dan agar dapat diterima dalam kelompok. Penyesuaian perilaku individu dengan lingkungannya dikenal sebagai konformitas. Konformitas dengan teman sebaya atau teman sekelas akan membuat nyaman seorang remaja untuk berada dalam lingkungannya, dan tanpa disadari seorang remaja rela menjadi korban dan pelaku bullying asalkan bisa diterima di lingkungannya. Bullying terbagi dalam dua bentuk 
utama, yaitu dapat berupa tindakan bullying yang dilakukan secara langsung seperti menyakiti, mengancam anak lain, atau menjelek-jelekkan secara verbal kepada anak lain. Sementara bentuk bullying yang dilakukan secara tidak langsung diantaranya adalah dengan cara menghasut, bersikap mendiamkan, atau dengan mengucilkan anak lain. Bullying baik secara langsung maupun tidak langsung yang dilakukan anak satu terhadap anak lainnya pada dasarnya mempunyai tujuan yang sama, yaitu untuk menekan korbannya, dan mendapat kepuasan dari perilaku tersebut. Pelaku bullying akan merasa puas ketika melihat ketakutan, kegelisahan, dan bahkan sorot mata permusuhan dari korbannya (Mashar \& Hidayah, 2011).

Menurut Espelage dan Swearer, dalam hal berkaitan dengan faktor sekolah seperti hal-hal yang berkaitan dengan instruksi akademik, manajemen kelas dan disiplin, serta sifat interaksi sosial di sekolah pantas mendapat perhatian yang lebih dalam memahami faktor dalam bullying yang terjadi di sekolah (Bibou-Nakou et al., 2012). Pencegahan terhadap perilaku bullying perlu dilakukan dan merupakan tanggung jawab semua elemen baik orang tua, sekolah, maupun pemerintah. Cara pencegahan yang dapat diterapkan adalah dengan memberikan pendidikan karakter pada anak sedini mungkin yang bertujuan untuk pembentukan konsep diri anak yang positif dan memperbaiki ego strength. Konsep diri positif dapat menghindarkan siswa untuk bertindak negatif seperti bullying. Ego strength merupakan kekuatan dari dalam diri seseorang, bila ego strength kuat maka tidak mudah terpengaruh oleh tindakan orang di sekitarnya terlebih untuk melakukan perbuatan negatif.

Pengabdian kepada masyarakat di Sekolah Menengah Pertama bermanfaat dalam mencegah perilaku bullying untuk mengurangi perilaku bullying sebagai pelaku dan untuk mencegah dampak psikologis terhadap korbannya, dan sekolah dapat menggunakan karya yang dihasilkan oleh pengabdi. Banyak permasalahan pada usia remaja antara lain yang dihadapi adalah banyaknya bullying di sekolah oleh sebab itu diperlukan pencegahan dalam bentuk pengabdian kepada masyarakat. Siswa Sekolah Menengah Pertama Negeri 02 Malang juga masuk masa perkembangan remaja awal, oleh sebab itu perlu dilakukan pencegahan perilaku bullying, sebelum terjadi kasus yang sulit diatasi. Gambaran masyarakat sasaran dalam pengabdian kepada masyarakat di Sekolah Menengah Pertama Negeri 02 Malang dilaksanakan pada kelas VIIA sampai VII F yang memiliki karakteristik permasalahan masing-masing kelas yang berbeda. Secara umum permasalahan yang kompleks dari diri siswa yang berasal dari budaya keluarga berbeda-beda, yang secara umum sudah membawa karakteristik ciri kepribadian yang berbeda dalam bentuk perilaku. Berdasarkan latar belakang pada perilaku siswa pada masa remaja yang sedang berada pada masa di Sekolah Menengah Pertama yang sangat rentan terhadap kejiwaannya, maka rumusan masalah dalam pengabdian kepada masyarakat adalah, bagaimana mencegah perilaku bullying di Sekolah Menengah Pertama Negeri 02 Malang Jawa Timur?.

Tujuan dari pengabdian kepada masyarakat pencegahan perilaku bullying di Sekolah Menengah Pertama Negeri 02 Malang adalah melakukan tindakan untuk mencegah perilaku bullying di Sekolah Menengah Pertama Negeri 02 Malang Jawa Timur. Capaian akhir dari pangabdian masyarakat dalam rangka membantu isu-isu bullying di sekolah akan dapat menjadi referensi bagi siswa, guru, masyarakat luas. 


\section{METODE}

Metode pelaksanaan yang diterapkan adalah tahap persiapan, tahap pemeriksaan psikologis yaitu BAUM, DAM, HTP dan Wartegg, tahap penyuluhan, tahap evaluasi pemeriksaan psikologis dan hasil karya sebagai laporan. Metode pelaksanaan pengabdian kepada masyarakat dimulai dari beberapa tahapan sebagai berikut.

1) Tahap Persiapan

Tahap persiapan dengan diawali perkenalan kepada Kepala Sekolah, Guru Bimbingan Penyuluhan, para Guru, Wali Kelas dan terhadap siswa dan orientasi lingkungan Sekolah Menengah Pertama Negeri 02 Malang. Pada proses awal pelaksanaan dimulai dari perkenalan dan permohonan ijin kepada Kepala Sekolah, setelah mendapatkan kesepakatan, selanjutnya perkenalan dengan para guru Bimbingan Konseling dan dengan para wali kelas. Selanjutnya melakukan tinjauan lapangan di lingkungan sekolah, meliputi fasilitas sarana dan prasarana sekolah halaman dan posisi kelas, observasi suasana atmosfir, situasi dan kondisi kelas. Berikutnya menentukan jadwal pelaksanaan untuk memulai masuk di kelas masing-masing. Pelaksanaan di kelas dimulai dengan perkenalan dengan memperkenalkan diri dan perkenalan dengan para siswa dan sekaligus observasi perilaku para siswa dan penjelasan awal tentang proses pencegahan perilaku bullying di sekolah.

2) Pemeriksaan Psikologis pre-test

Pemeriksaan psikologis dilakukan untuk mengetahui kondisi psikologis siswa tentang kecencderungan pelaku bullying melalui tes BAUM, DAM, HTP dan Wartegg. Tujuanya untuk mengetahui ciri kepribadian anak agar dapat dijadikan panduan dalam membimbing siswa di sekolah dan menentukan tindak lanjutnya apabila ada kasus kejiwaan yang serius.

3) Penyuluhan

Melakukan penyuluhan dengan materi tentang perilaku bullying di sekolah terkait dampak terhadap korban bulling dan pelaku bullying. Materi berikutnya adalah tata cara tentang pencegahan perilaku agresifitas dan berbicara santun sebagai materi pencegahan terhadap perilaku bullying di sekolah. Materi penyuluhan tentang pencegahan perilaku bullying yang diberikan di Sekolah Menengah Pertama disesuaikan dengan kejiwaan para remaja di sekolah. Metode penyampaian dengan ceramah menggunakan pawer poin dan menggunakan fasilitas Liquid Crystal Display, alat tulis dan peraga. Waktu penyuluhan yang disediakan oleh sekolah adalah pada waktu jam Pembinaan Karakter Siswa untuk masing-masing kelas secara bergantian. Muatan materi yang diberikan pencegahan perilaku bullying dan pemberian tata cara mencegah perilaku agresif dan tata cara berbicara santun.

4) Pemeriksaan Psikologis post-test

Pemeriksaan psikologis kedua dilakukan sebagai evaluasi psikologis melalui tes BAUM, DAM, HTP dan Wartegg sebagai post test. Hasil pemeriksaan psikologis di lakukan untuk mengetahui ciri kepribadian anak agar dapat dijadikan panduan dalam membimbing anak di sekolah dan tindak lanjutnya apabila ada kasus kejiwaan yang seriu.s

5) Hasil Karya sebagai pelaoran

Seluruh proses dari awal mulai dari tahap perssiapa, pemeriksaan psikologis pree dan tahap evaluasi dengan pemeriksaan psikologis, yang dihasilkan yang mengindikasikan adanya pelaku bullying dan dampaknya akan adanya korban bullying. Maka pengabdian masyarakat ini dapat di jadikan bahan untuk menyusun buku pedoman dalam menangani pelaku dan korban bullying di sekolah. 


\section{HASIL KARYA UTAMA DAN PEMBAHASAN}

Selama proses kegiatan maka dikumpulkan seluruh data dokumen digunakan untuk menyusun menjadi suatu karya yang dapat digunakan oleh para guru di sekolah. Setelah disusun dari seluruh kegiatan dapat dijadikan menjadi karya utama dalam bentuk panduan untuk mencegah perilaku bullying dan mengurangi korban bullying adalah sebuah buku panduan. Proses dalam mencari solusi pemecahan masalah perilaku bullying di sekolah di dapatkan data sebagai pendukung mendapatkan solusi untuk mengatasi perubahan perilaku terkait bullying. Pada tahap evaluasi di dapatkan penurunan sebagai pelaku bullying yang mengindikasikan bahwa adanya perubahan perilaku dalam setelah dilakukan penyuluhan pencegahan perilaku bullying. Kegiatan analisis data dari pre-tes dan post-test dari seluruh hasil kegiatan mulai dari persiapan dan pengenalan lingkungan melalui observasi lingkungan sampai pada penyuluhan dan dilanjutkan dengan evaluasi pemeriksaan psikologis dapat dideskripsikan melalui tahap pemeriksaan kepribadian yaitu BAUM, DAM, HTP dan Wartegg, tahap penyuluhan, tahap evaluasi pemeriksaan kepribadian dan hasil karya sampai pelaporan dimulai dengan proses sebagai berikut.

1) Persiapan

Secara umum lingkungan di lokasi sekolah kondusif alami dengan difasilitasi rumah gazebo untuk sarana edukatif dan lapangan bermain yang cukup, lingkungan halaman yang asri dengan tanaman yang ditata rapi, disela-sela tanaman terdapat kran tempat cuci tangan dan sekaligus bisa digunakan untuk wudhu untuk menjalankan ibadah, apalagi posisi tempat air berada di dekat Masjid sekolah. Adanya lorong terbuka yang rimbun dengan tanaman dan cat tembok warna di dalam kelas, dan banyak dilengkapi dengan CCTV. Tetapi dengan sejumlah siswa yang banyak dan pada masa remaja yang memiliki karakristik dari budaya yang berbeda tampak ramai lalu lalang siswa dengan berbagai interaksinya. Budaya keluarga yang berasal dari pola asuh keluarga melekat dan sudah menjadi bentuk ciri kepribadian yang berbeda pada anak sejak kecil sampai pada masa remaja yang sedang duduk di Sekolah Menengah Pertama.

2) Pemeriksaan Psikologis Pre-test

Fenomena yang ada di sekolah adalah seringnya perilaku kasar dalam berbicara, memaki teman, bicara nada tinggi, mengomel sendiri, mengejek teman, membanting buku, kontak fisik perilaku bullying. Adanya perilaku pembiaran terhadap teman yang butuh bantuan karena korban bullyng terhadap temannya, pendiam, tidak ada semangat, beberapa merasa cemas, kurang berani mengungkapkan perasaannya. Aspek lainnya adalah interaksi antar siswa dari berbagai kelas dan dari berbagai tingkat kelas yang memungkinkan adanya gesekan kepribadian dan perilaku termasuk perilaku bullying di sekolah yang sangat mudah akan dapat terjadi. Foto di dalam kelas selama proses pemeriksaan pskologis ditunjukkan pada gambar berikut.

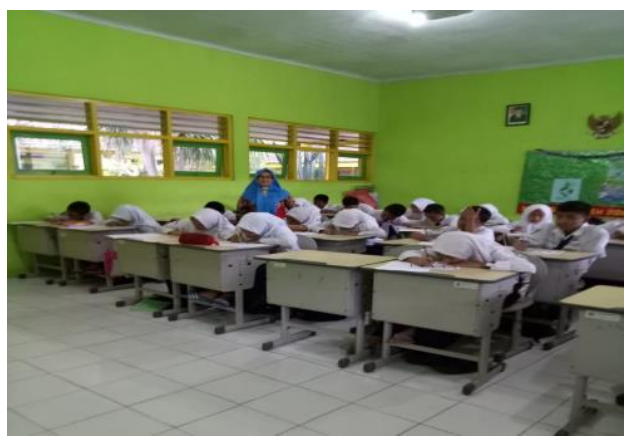

Gambar 1. Pemeriksaan Psikologis Pre-Test 
Jumlah siswa yang mengikuti pemeriksaan psikologis adalah 172 orang, hasil interpretasi pemeriksaan psikologis pada pre-test adalah adanya beberapa pelaku aktif pelaku bullying dan korban bullying sebesar 25\%. dan hasil post-tes sebesar $22 \%$ sisanya dalam kondisi aman sebagai hasil awal temuan, pada tabel berikut.

Tabel 1. Pemeriksaan Psikologi Pre Test

\begin{tabular}{|c|l|c|}
\hline No & \multicolumn{1}{|c|}{ Kecenderungan } & Persentase \\
\hline 1 & Pelaku Bullying & $25 \%$ \\
\hline 2 & Koban Bullying & $22 \%$ \\
\hline 3 & Aman & $58 \%$ \\
\hline & Total & $100 \%$ \\
\hline
\end{tabular}

\section{3) Penyuluhan}

Sifat khusus dari siswa Sekolah Menengah Pertama adalah karakteristik siswa berada pada masa remaja yang masih labil dalam mengekspresikan perasaannya, kemarahannya. Tampak bahwa pada masing-masing kelas adalah adalanya pelaku-pelaku perilaku bullying dan korban bullying. Sejumlah siswa yang perlu mendapatkan treatment antara pelaku dan korban bulling di sekolah adalah diperlukan strategi pengelolaannya. Foto kegiatan ditampilkan pada pada gambar berikut.

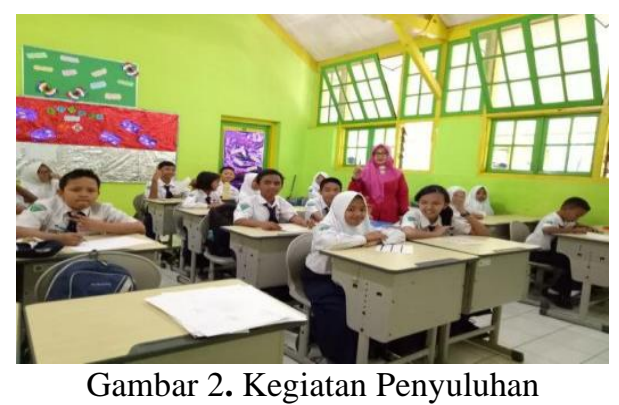

\section{4) Pemeriksaan Psikologis Post-Test}

Fenomena yang ada di sekolah terbanyak adalah perilaku bullying terhadap temannya yang dapat di cegah dengan strategi dengan perlakuan melalui strategi pendekatan terhadap siswa, melalui penyuluhan dengan metode ceramah terhadap siswa . Kondisi yang terkait dengan fenomena perilaku bullying di sekolah dapat dipengaruhi dengan tindakan interaksi dengan siswa yang memiliki karakteristik yang berbeda ada yang keras kepala ada yang fleksibel. Untuk yang keras kepala dan sifat yang kaku akan memerlukan perhatian khusus dalam penanganan, dan pada golongan kepribadian yang cenderung melakukan tindak perilaku bullying Tetapi bagi siswa yang memiliki karakteristik ciri kepribadian yang fleksibel akan mudah dipengaruhi dengan oleh model perilaku baik yang ditampilkan dan bersedia menerima saran dari orang lain.Kegiatan dalam kelas ditampilkan pada gambar berikut. 


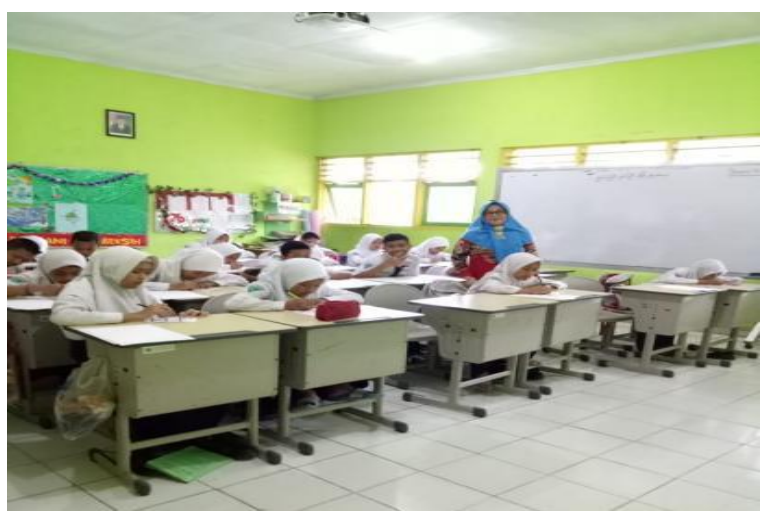

Gambar 3. Pemeriksaan Psikologis Post-Test

Hasil temuan setelah penyuluhan tentang pencegahan peilaku bullying maka di dapatkan penurunan pelaku bullying dan korban hasil pemeriksaan psikologis pelaku bullying $5 \%$ dan korban bullying $10 \%$. sisanya adalah kondiisi aman, pada tabel berikut.

Tabel 2. Pemeriksaan Psikologi Post Test

\begin{tabular}{|c|l|c|}
\hline No & \multicolumn{1}{|c|}{ Kecenderungan } & Persentase \\
\hline 1 & Pelaku Bullying & $5 \%$ \\
\hline 2 & Koban Bullying & $12 \%$ \\
\hline 3 & Aman & $82 \%$ \\
\hline & Total & $100 \%$ \\
\hline
\end{tabular}

\section{5) Hasil Karya Utama}

Kegiatan setelah mengetahui karakteristik kepribadian siswa, akan digunakan untuk dasar melaksanakan tujuan dari pengabdian masyarakat dan menjadi semakin mudah untuk membimbing siswa berdasarkan ciri kepribadiannya. Setelah mengetahui kepribadian siswa maka dilakukan pembinaan pencegahan terhadap perilaku bullying melalui penyuluhan yang berorientasi pada materi tindakan bullying oleh pelaku dan korban bullying pada siswa di sekolah. Pencegahan perilaku bullying di sekolah perlu secepatnya dilakukan suatu cara agar dapat mengurangi dan mencegah tindakan yang merugikan pada siswa saat di sekolah. Berdasarkan hasil pemeriksaan psikologis dan penyuluhan tentang pencegahan terhadap perilaku bullying mendapatkan hasil dapat mencegah dan dapat mengurangi perilaku bullying yang di lakukan oleh siswa di sekolah. Fenomena yang ada di sekolah sangat dibutuhkan suatu cara dalam menangani isu bullying para siswa. Oleh sebab itu di susun tahapan yang telah dilakukan pada pengabadian masyarakat menjadi bentuk sebuah buku panduan dalam mengatasi isu yang ada di lapangan uatamanya di sekolah.

Bullying merupakan suatu perilaku berulang yang dilakukan secara agresif dan sengaja baik secara fisik maupun verbal terhadap orang lain yang lebih lemah dan tidak mampu memberikan perlawanan. Bullying terjadi karena disebabkan oleh faktor yang kompleks baik dari dalam diri sendiri seperti sifat agresif, kurangnya kontrol diri, konsep diri, ataupun faktor dari luar seperti pergaulan, hubungan orang tua dan anak, dan kurangnya kontrol sosial. Menurut Rigby, hubungan orang tua dan anak adalah faktor penting, anak yang memiliki hubungan positif dengan orang tuanya cenderung lebih sedikit ikut berperan melakukan bullying (Omoteso, 2010).

Coloroso (2007) menyatakan bahwa yang biasanya menjadi korban bullying adalah anak yang baru tinggal di suatu lingkungan, anak yang usianya lebih muda di sekolah, karena biasanya anak yang lebih muda usianya, terkadang akan merasa ketakutan, dan kurang terlindungi, anak-anak yang pernah mengalami trauma atau pernah disakiti 
sebelumnya sehingga biasanya akan menghindari teman sebaya untuk tidak mengalami kesakitan yang lebih parah, dan anak-anak yang merasa sulit untuk meminta pertolongan. Selain itu juga anak penurut, anak yang memiliki rasa cemas, kurang percaya diri, mudah dipimpin dan anak yang melakukan hal-hal untuk menyenangkan atau meredam kemarahan orang lain, anak yang perilakunya dianggap mengganggu orang lain, anak yang tidak mau bekelahi, lebih suka menyelesaikan konflik tanpa kekerasan, anak yang pemalu, menyembunyikan perasaan, pendiam atau tidak mau menarik perhatian orang lain, penggugup, dan peka (Coloroso, 2007).

Keunggulan hasil karya dalam bentuk buku panduan dalam mencegah perilaku bullying tidak dapat digunakan untuk khusus S ekolah Menengah Pertaman sehingga dapat secara spesifik terfokus pada siswa SMP. Kelemahan hasil karya dalam bentuk buku panduan dalam mencegah perilaku bullying tidak dapat digunakan untuk Sekolah Menengah Atas atau di Perguruan Tinggi dan perilaku bullying di dalam keluarga, tetapi secara umum masih dapat digunakan.

Hasil pengabdian kepada masyarakat merupakan karya baru yang sebelumnya di sekolah belum tersedia buku panduan yang bersifat penangananan psikologis. Kegiatan yang dimulai dari pelaksanaan kegiatan pengabdian masyarakat yang dimulai dengan pengenalan lingkungan terhadap suasana sekolah secara keseluruhan adalah terkesan sejuk banyak bunga dan tanaman pohon yang terkesan sekolah hijau di dukung pula dengan cat tembok sekolah berwarna hijau yang terkesan sejuk dan damai. Hubungan antar wali kelas, guru dengan siswa pada jam belajar di sekolah terpantau oleh camera CCTV yang terdapat di berbagai sudut kelas dan jalan masuk kelas, halaman sekolah yang cukup luas. Hubungan antara guru dan siswa di luar jam sekolah dikendalikan secara kekeluargaan pada pembimbingan melalui whatsapp grup antar wali kelas dengan para siswa, sehingga mudah terpantau dalam kehidupan berinteraksi di sekolah.

Hasil pemeriksaan psikologis dan hasil observasi dan pemeriksaan psikologis ditemukan beberapa karakteristik kepribadian sebagai berikut. Pertama adalah pelaku bullying, yaitu ada beberapa siswa yang memiliki emosi mudah marah, mudah tersinggung, adanya keinginan untuk mengekplorasikan emosinya, bicaranya kasar, mudah memaki, sarkastik dan memaki secara oral, perilaku kurang santun, sering bertanya, dan mudah melakukan perilaku bulying, sombong. Kondisi afek yang mudah berprasangka negatif dan tetapi sebenarnya anak kurang percaya diri, dan ingin menyampaikan perasaannya. Kedua adalah keompok korban bullying, ada beberapa siswa yang memiliki kepribadian tertutup, sikap santun, kurang percaya diri, motivasi rendah dan adanya keinginan memaki secara oral, merasa cemas sampai pada tanda-tanda depresi ringan. Ketiga yaitu beberapa siswa yang memiliki sikap yang santun, motivasi tinggi dan aman dari pelaku dan aman tidak mendapatkan perlakuan bullying dari temannya, memiliki rasa percaya diri yang kaut.

Pada saat awal proses pelaksanaan penyuluhan berlangsung masih terdapat berapa siswa yang berperilaku kurang santun, perilaku kasar, mengejek dan teriak pada temannya dan kontak fisik terhadap teman sekelasnya. Terdapat juga beberapa siswa sewaktu masuk kelas dan akan dududk di meja ada yang berperilaku agresif dalam bentuk kontak fisik dan bahasa membentak keras terhadap temannya dengan maksus melaorkan kejekan temannya. Tetapi setelah menyimak materi penyuluhan tentang dampak pada korban dan pada pelaku yang melakukan perilaku bullying, perlahan mulai tampak diam dan mencerna materi dengan menyimak lebih tenang, gerakan badannya mulai berkurang, banyak diam memperhatikan satu persatu materi penyuluhan yang disampaikan. Setelah akhir dari penyuluhan tampak mulai ada penurunan agresifitas 
secara oral mulai berkurang dan lebih baik lagi mulai meminta maaf terhadap temannya dan meminta maaf terhadap penyuluh.

Isu-isu pada masa remaja terkait penanganan masalah bullying memerlukan metode yang tepat agar dapat dipergunakan. Alat dalam metode ini yang digunakan adalah alat tes psikologi tes BAUM, DAM, HTP dan Wartegg untuk mengukur kondisi kepribadian dan bahan materi penyuluhan pencegahan terhadap perilaku bullying dan metode sebagai karya yang dihasilkan adalah metode yang belum tersedia di sekolah yaitu Buku Panduan dalam menangani masalah bullying di sekolah. Metode penyampaian penyuluhan dengan ceramah menggunakan power poin dan menggunakan fasilitas Liquid Crystal Display, alat tulis dan peraga.

Pembahasan pada masalah yang ada di sekolah antara lain adalah tindakan aytau perilaku bullying siswa terhadap temannya, dalam bentuk memaki, mengejek, mrngisolasi temannya, memukul, menendang. Perilaku bullying ini perlu mendapat pencegahan oleh guru di sekolah sebelum menjadi perilaku yang lebih agresif. Setelah dilaksanakan pencegahan tehadap perilaku bullying, hasil kegiatan pencegahan terhadap perilaku bullying adalah terdapat penurunan tindak perilaku bullying di sekolah.

Hasil pemeriksaan psikologis terdapat terdapat perbedaan kepribadian anak setelah dilakukan pemeriksaan psikologis yaitu ada beberapa siswa memiliki emosi mudah marah, mudah tersinggung, adanya keinginan untuk mengekplorasikan emosinya, bicaranya kasar, mudah memaki, sarkastik dan memaki secara oral, sombong, perilaku kurang santun, dan mudah melakukan perilaku bulying. Perilaku yang tampak selama observasi dan tidak tampak pada hasil tes psikologi adalah didapatkan perilaku bullying yang dilakukan oleh beberapa orang siswa perilaku bullying dan cenderung mengarah pada perilaku agresifitas. Kondisi afek yang mudah berprasangka negatif dan tetapi sebenarnya anak kurang percaya diri, dan ingin menyampaikan perasaannya. Kondisi afek atau perasaan yang berprasangka buruk terhadap orang lain

Menurut Newstorm dan Davis (1997) agresivitas merupakan tindakan yang berdasar kemarahan dapat meliputi perkelahian, perusakan properti atau melukai bahkan membunuh orang lain. Agresivitas dapat menjadi produk dari stres orang lain (Newstrom \& Davis, 1997). Kasus-kasus bullying yang terjadi menurut Luthar, sejalan dengan perlakuan negatif yang berlangsung terus menerus pada anak. Paparan perlakuan negatif dapat terjadi dalam bentuk kekerasan secara berkelanjutan yang memiliki efek sangat negatif terhadap perkembangan anak, seperti munculnya gangguan kecemasan, depresi, dan mengalami penurunan kemampuan belajar dikarenakan ia mengalami kesulitan konsentrasi dan penurunan dalam memorinya sehingga dapat mempengaruhi prestasi akademis siswa secara signifikan (Hidayati, 2012).

Latar belakang beberapa siswa yang berasal dari budaya keluarga yang orang tuanya dalam perannya membimbing pada masa perkembangan anak, di dapatkan pula yang dapat berdampak pada tindakan bullying oral terhadap temannya. Siswa yang sepanjang hidupnya misalnya sudah nampak perilaku yang menunjukkan tanda-tanda gangguan, dan melanggar aturan di keluarga, di sekolah dan di masyarakat, akan selalu berperilaku tidak berbertanggung jawab terhadap dirinya sendiri dan semakin bertambah parah dan dapat merugikan orang lain. Seterusnya akan tidak mampu mengendalikan impuls dan dapat terjadi ledakan kemarahan yang tidak terkendali, pada saat terjadi peristiwa tertentu. Siswa yang kesulitan mengendalitan impuls akan dapat melakukan tindakan yang merugikan siswa lain misalnya memaki, mengancam dan benar-benar melakukan tindak kekerasan dan penganiayaan terhadap teman yang membuat dirinya tersinggung. Ciri kepribadian siswa juga dapat mengalami gangguan yang di sebut gangguan kepribadian apabila mengalami hambatan dalam masa perkembangan. Gambaran dari 
gangguan kepribadian pada siswa dapat berupa tanda-tanda kenakalan pada remaja, suka marah pada temannya, mengejek, memaki dan merusak barang temannya. Apabila ada seorang remaja yang sejak kecil menunjukkan sifat yang membantah, selalu melakukan perilaku yang melanggar aturan dan perintah orang tua dan guru, walaupun telah diperingatkan berulang-ulang dan di hukum tetap sering melakukan dan menunjukkan perilaku di luar kewajaran usia anak remaja, maka perlu mendapatkan perhatian khusus oleh orang tua dan guru di sekolah.

Pada aspek perkembangan anak terdapat masalah dalam perkembangan emosional anak pelaku bullying ketika anak ingin mendapatkan kesenangan dengan membully temannya. Pada penelitian ini sebagian besar pelaku bullying $(52,1 \%)$ melakukan tindakan bullying agar mendapatkan suasana yang menyenangkan. Pola asuh otoriter menimbulkan tekanan dalam diri anak, sehingga anak mencari kepuasan dan perasaan senang pada lingkungan lain seperti sekolah. Ini merupakan masalah dalam perkembangan moral dan perilaku anak ketika anak belum mampu memahami emosi yang kompleks yang terintegrasi dengan rasa tanggung jawab akibat dari perilakunya, dan tidak mampu menunjukkan rasa empati pada korban bullying (Santrock, 2011).

Setelah mendapatkan penyuluhan tentang materi bullying tampak pada observasi adanya penurunan perilaku antara lain cara bicara mulai menurunkan nada suar, mulai saling menghormati temannya walaupunkadang masih ada sisa dengan kontak verbal agak kasar membentak. Sejalan dengan tujuan pengabdian masyarakat adalah untuk menurunkan dan mencegah bullying Siswa yang memiliki sikap santun dengan motivasi yag tinggi dan berlatar belakang dari keluarga yang harmonis sebenarnya dapat di motivasi dapat dijadikan contoh untuk membimbing siswa yang lain agar berperilaku kelompok yang baik seperti model temannya sendiri. Ciri kepribadian yang kaku akan terus melekat sampai diakhir usianya. Siswa yang pendiam, pemalu, kurang paham terhadap permasalahan yang dihadapi, sering bertanya kepada orang lain dan kurang percaya diri, motivasi rendah, membutuhkan semangat yang penuh dari keluarga dan dari sekolah, dan dapat menjadi sasaran korban bullying. perbaiki kemauan yang keras agar dapat mengikuti aturan yang berlaku dan dapat merasakan kehidupan persekolahan yang nyaman. Berbagai budaya itu antara lain siswa ada yang dari berasal pola asuh keluarga dengan pernikahan yang utuh ayah dan ibu kandung, ayah dan ibu yang cerai dan yang meninggal, diasuh oleh seorang ibu yang harus bekerja keras untuk mencukupi kehidupan keluarganya, diasuh oleh saudara, pulang sekolah sendirian tanpa teman yang menemani karena orang tua pulang larut malam, pola asuh yang terdiri dari keluarga yang besar adanya nenek, kakek, paman, bibi, saudara sepupu yang ada dalam keluarga masing. Budaya yang lain adalah budaya keluarga dengan adanya kebiasaan kekerasan yang dialami oleh anak atau siswa, kata-kata kasar, kata-kata bernada tinggi, teriakan, memaki dan memukul anak, pandangan mata yang acuh dan sinis pada anak, menghina keburukan anak dan membandingkan dengan saudara dan orang lain yang memiliki prestasi lebih tinggi dari orang lain. Sedangkan sebaliknya adanya budaya keluarga yang lain berasal dari kebiasaan bahasa yang santun, biasa menggunakan bahasa yang beradab, perilaku yang membimbing dan memberikan contoh yang baik pada anak dan keluarga yang harmonis dan saling menjadi model untuk semua anggota keluarga dan menjadi penyemangat pada anak sesuai dengan usianya. Tetapi apabila ada siswa yang diluar model maka dapat di berikan yang lain antara lain dengan terapi perilaku dan dapat di modifikasi dengan terapi yang tepat lainnya (Weeks, 2000).

Teknik terapi perilaku adalah penerapan aneka ragam teknik dan prosedur yang berakar berbagai teori tentang belajar. Menyertakan penerapan yang sistematis prinsipprinsip belajar pada pengubahan perilaku ke arah cara-cara yang lebih adaptif. 
Pendekatan yang memberikan sumbangan-sumbangan yang berarti baik pada bidangbidang klinis maupun pendidikan (Corey, 2009).

Demikian juga yang ditemukan pada siswa kelas VII secara umum terdapat beberapa siswa yang melakukan perilaku yang kesulitan mengendalikan impuls seingga mudah melakukan perilaku bullying terhadap temannya. Oleh sebab itu tampak bahwa berbagai karakteristik yang terdapat pada siswa kelas VII perlu mendapatkan penyuluhan secara kolektif dan konseling individu dan pada siswa yang mengalami traumatik pada korban bullying perlu mendapat psikoterapi. Psikoterapi yang tepat untuk siswa adalah support terapi dan dapat di lanjutkan dengan pendekatan dan teknik Adlerian Terapi dan Behavior Terapi. Menurut Murphy ada karakteristik internal yang dimiliki oleh korban bullying yakni anak-anak yang menjadi korban biasanya memiliki jenis kepribadian pasif dan submisif. Anak-anak ini cenderung tidak mampu mempertahankan diri mereka dan hakhak mereka, walaupun tidak sedang dalam situasi menjadi target bullying. Karakteristik lain yakni korban bullying biasanya memiliki kecemasan, kegugupan, ataupun rasa tidak aman. Mereka juga cenderung merupakan anak yang pemalu dan pendiam (Hidayati, 2012)

Kepribadian merupakan gabungan dari segala sifat, dan pola reaksi dan perilaku seseorang yang memberikan ciri khas, dalam menentukan sikap dan daya penyesuaian seseorang terhadap lingkungannya, yang relatif menetap dan dapat diperkirakan sebelumnya. Kepribadian setiap individu menunjukkan perbedaan dalam tempramen, disposisi atau karakter (Funder, 2001; Pervin \& John, 2001; Purnamaningsih, 2015).

Perilaku bullying berdampak sangat mengganggu fungsi dalam kehidupan korban bullying di sekolah. Korban bullying dapat menyebabkan rasa rendah diri, traumatik, dan beberapa adanya keluhan malas sekolah dan ingin pindah sekolah lain pada siswa korban bully. Korban dari bullying berdampak pada korban bullying menjadi semakin tidak nyaman berada dilingkungan sekolah. Sedangkan siswa yang memiliki ciri kepribadian tertutup, sikap santun, kurang percaya diri, motivasi rendah dan adanya keinginan memaki secara oral. Individu yang memiliki kepribadian tertutup tetapi juga santun, kemungkinan adanya perasaan tertekan dan ingin mengungkapkan perasaannya terhadap orang lain, biasanya pada anak remaja lebih memilih mengeluarkan isi perasaannya kepada teman sebaya, dan yang memiliki sikap yang santun, motivasi tinggi, dan berlatar belakang budaya keluarga yang dari lingkungan yang memiliki peran ibu dan ayah yang sesuai dan seimbang serta harmonis. Dampak bullying yang cenderung mengakibatkan gangguan keseimbangan kejiwaan seseorang membutuhkan penanganan yang tepat, oleh sebab itu tujuan dari pengabdian adalah mencega terjadinya perilaku bullying, sebelum berdampak kurang baik terhadap perkembangan kejiawaan anak.

Bullying merupakan suatu perilaku agresif yang dilakukan oleh seseorang atau kelompok terhadap orang-orang atau kelompok baik secara langsung ataupun tidak langsung, yang dilakukan secara berulang-ulang dengan cara menyakiti secara fisik maupun mental orang lain (Prasetyo, 2011; Sari, 2017). Dampak bullying bisa jangka pendek dan bisa seumur hidup, dalam kasus seperti ini, sebaiknya jangan meremehkan apa yg dirasakan korban karena sangat menyakitkan, mengesalkan dan menakutkan. Korban menjadi takut ke sekolah dan kehilangan rasa percaya diri (Mashar \& Hidayah, 2011).

Masih ditemukannya kasus-kasus bullying di Sekolah Menengah Pertama merupakan suatu masalah yang memerlukan penanganan secara serius untuk mengurangi dan sekaligus tindakan pencegahan terhadap perilaku yang dapat merugikan siswa yang lain. Maka sesuai dengan tujuan dari pengabdian masyarakat di sekolah adalah untuk mencegah perilaku bullying, sehingga perlu dikemas suatu bentuk penanganan yang 
dapat di terapkan di sekolah. Sumbangan yang diberikan dari seluruh hasil kegiatan pengabdian yaitu suatu cara dalam penanganan pencegahan perilaku bullying siswa yang dapat digunakan sebagai panduan oleh para guru terutama guru bimbingan dan konseling dan wali kelas di sekolah. Buku panduan yang disumbangkan mendapat respon positif dari guru bimbingan konseling, Kepala Sekolah memberikan support dan wali kelas dan para guru lainnya pada setiap kegiatan selalu di bantu mulai dari awal sampai akhir. Setelah kegiatan pengabdian masyarakat diketahui bahwa siswa membutuhkan penanganan tentang bagaimana cara untuk mencegah perilaku bullying di sekolah dan para guru membutuhkan cara penangannya. Maka perlu dikemas suatu bentuk yang dapat menjadi suatu karya yang dapat disumbangkan ke sekolah dalam menangani masalahmasalah yang terkait dengan kasus bullying di sekolah. Karya pengabdian yang dapat di sumbangkan dalam kepada sekolah dan pelaporan yaitu: 1) Hasil pemeriksaan psikologis dari seluruh siswa kelas VII yang dapat digunakan untuk membimbing siswa jika terjadi suatu masalah psikologis dan perilaku bullying untuk mempermudah pendekatan secara psikologis terhadap siswa yang bermasalah. 2) Materi Penyuluhan tentang pencegahan terhadap perilaku bullying di sekolah, dapat di gunakan untuk melaksanakan penyuluhan yang dapat di berikan oleh para guru Bimbingan Konseling pada saat jam pembentukan karakter siswa. 3) Buku Panduan tatalaksana pencegahan perilaku bullying disekolah yang dapat digunakan dalam penanganan kasus-kasus khususnya perilaku bullying oleh siswa di sekolah. 4) Laporan yang perlu diselesaikan adalah karya dalam suatu jurnal ilmiah.

\section{KESIMPULAN}

Buku panduan telah tercapai sebagai buku yang dapat sepenuhnya dapat digunakan untuk menyelesaikan permasalahan di sekolah. Berbagai upaya yang telah banyak dilakukan oleh para guru di sekolah tiada henti, namun masa perkembangan kejiwaan siswa terus semakin berkembang, ada yang baik dan ada yang buruk, sehingga diperlukan upaya yang saat ini diperlukan sesuai dengan kasus-kasus sehari-hari, agar mudah diterapkan. Demikian juga upaya dalam kegiatan pengabdian di sekolah ini adalah bertujuan untuk mencegah perilaku bullying, oleh sebab itu maka seluruh hasil yang telah dilaksanakan oleh pengabdi dapat di sumbangkan kepada sekolah dalam bentuk suatu cara penanganan pencegahan bullying siswa di sekolah, yang dapat di gunakan sebagai panduan oleh para guru di sekolah utamanya guru Bimbingan Konseling.

Penanganan pada siswa pelaku bullying perlu di cegah dan korban dari pelaku bullying perlu mendapatkan pertolongan dalam bentuk konseling dan psikoterapi. Demikian pula sebaliknya dilakukan penanganan terhadap pelaku bullying, sebelum menjadi budaya bullying di sekolah yang dapat cenderung malakukan penganiayaan dan masuk pada kriteria pelanggaran hukum. Dalam membimbing siswa yang masih remaja ini memerlukan suatu cara penanganan yang mudah dipahami oleh anak usia remaja utamanya dalam pencegahan perilaku bullying. Kegiatan yang cocok untuk anak remaja adalah menentukan materi yang tepat untuk penyuluhan tentang pencegahan terhadap perilaku bullying di sekolah, yang dapat di gunakan untuk melaksanakan penyuluhan oleh para guru Bimbingan Konseling pada saat jam pembentukan karakter siswa. Proses berikutnya perlu pemeriksaan psikologis dengan tujuan agar mudah membimbing siswa jika terjadi suatu masalah psikologis di sekolah sebagai rekam psikologis masing-masing siswa.

Pemecahan masalah yang berorientasi pada psikologi pendidikan dan psikologi klinis untuk mengatasi masalah di sekolah. Masalah yang ada di sekolah adalah terdapatnya perilaku bullying yang dilakukan oleh siswa sekolah menengah pertama 
yang masih dalam masa perkembangan kepribadian. Masa perkembangan kepribadiannya di iringi dengan masa pertumbuhan fisik dan perubahan hormonal sehingga sering menimbulkan ketidakseimbangan kejiwaan, suasana perasaan dan emosional yang sering di sebut masa badai dan stres. Masa perkembangan inilah yang sering menimbulkan masalah suasana perasaan dan perilaku yang sering berubah-ubah diantaranya senang, benci, pamalu, pendiam kemarahan dan mengejek, mengolok sampai para perilaku kasar dan kontak fisik yang cenderung kearah perilaku bullying dan berdampak merugikan kejiwaan korban bully. Agar masalah tidak semakin parah oleh sebab itu perilaku bullying yang cenderung menimbulkan dampak buruk terhadap siswa yang lain maka perlu di tangani secara serius dan berkelanjutan.

Kontribusi bagi masyarakat dari temuan pada beberapa siswa yang memerlukan perhatian khusus dan pada orang tua siswa dan para guru di sekolah, serta kepala sekolah dalam mengambil kepusan dalam menentukan kebijakan. Memahami dan memberikan perhatian penuh terhadap kebutuhan fisik dan psikologis anak utamanya menanamkan budaya santun terhadap otrang lain di rumah dan nasehat yang sesuai dengan karakter anak menuju sekolah. Guru Bimbingan dan Konseling Memberikan perencanaan dan pembinaan terprogram secara berkala terhadap siswa tentang hubungan dalam berinteraksi yang santun, dan memberikan konseling individual dan kelompok dan merujuk siswa yang bermasalah psikologis di sekolah. Kepala Sekolah dalam menentukan program khususnya untuk siswa yang bermasalah dengan mengambil kebijakan membuat program pelatihan kepada para guru tentang penanganan bullying di sekolah.

\section{DAFTAR RUJUKAN}

Bibou-Nakou, I., Tsiantis, J., Assimopoulos, H., Chatzilambou, P., \& Giannakopoulou, D. (2012). School factors related to bullying: A qualitative study of early adolescent students. Social Psychology of Education, 15(2), 125-145. https://doi.org/10.1007/s11218-012-9179-1

Brookmen, F., Maguire, M., Pierpoint, H., \& Bennet, T. (2010). Hanbook on crime. Willan Publishing.

Coloroso, B. (2007). Stop Bullying: Memutus Rantai Kekerasan Anak dari Prasekolah hingga SMU. Diterjemahkan oleh: Santi Indra Astuti. PT. Serambi Ilmu Semesta.

Corey, G. (2009). Theory and Practice of Counseling and Psychotherapy (8th ed.). Thomson Brook/Cole.

Fithria, F., \& Aulia, R. (2016). Faktor-Faktor yang Berhubungan dengan Perilaku Bullying. Idea Nursing Journal, 7(3), 9-17. https://www.google.com/url?sa=t\&rct=j\&q=\&esrc=s\&source=web\&cd=2\&cad=rj a\&uact=8\&ved=2ahUKEwimuKGa77npAhUY7HMBHQgOAHIQFjABegQIAxA B\&url=http\%3A\%2F\%2Fwww.jurnal.unsyiah.ac.id\%2FINJ\%2Farticle\%2FviewFi le\%2F6440\%2F5277\&usg=AOvVaw2TdAyA0DRM6G2MBn5Re6_6

Funder, D. C. (2001). Personality. Annual Review of Psychology, 52, 197-221.

Hidayati, N. (2012). Bullying pada Anak: Analisis dan Alternatif Solusi. 14(01), 41-48.

Kertamuda, F. E. (2009). Konseling Pernikahan Untuk Keluarga Indonesia. Salemba Humanika.

Mashar, R., \& Hidayah, S. N. (2011). Bullying di sekolah. Edukasi Jurnal Penelitian Dan Artikel Pendidikan, 3(6), 1-17.

Newstrom, J. W., \& Davis, K. (1997). Organizational behavior: Human behavior at work. McGraw-Hill.

Omoteso, B. A. (2010). Bullying behaviour, its associated factors and psychological 
effects among secondary students in nigeria •. The Journal of International Social Research, 3(1996), 498-509.

Pervin, L. A., \& John, O. P. (2001). Personality, 8th Edition. John Wiley \& Sons Inc: New York.

Prasetyo, A. B. E. (2011). Bullying di Sekolah dan Dampaknya bagi Masa Depan Anak. El-Tarbawi, 4(1), 19-26. https://doi.org/10.20885/tarbawi.vol4.iss1.art2

Purnamaningsih, E. H. (2015). Kepribadian Dan Memori. Buletin Psikologi Universitas Gadjah Mada. Fakultas Psikologi, 16(2), 94-97. https://doi.org/10.22146/bpsi.7377

Santrock, J. W. (2011). Perkembangan Anak (Terjemahan: Sarah Genis B) (Edisi 7). Penerbit Erlangga.

Sari, E. P. (2017). Faktor Yang Mempengaruhi Bullying Pada Anak Usia Sekolah Di Sekolah Dasar Kecamatan Syiah Kuala Banda Aceh. Faktor Yang Mempengaruhi Bullying Pada Anak Usia Sekolah Di Sekolah Dasar Kecamatan Syiah Kuala Banda Aceh, 8(3).

Setyawan, D. (2014). KPAI : Kasus Bullying dan Pendidikan Karakter. 16 Oktober 2014. http://www.kpai.go.id/berita/kpai-kasus-bullying-dan-pendidikan-karakter/

Ulfiah, U. (2016). Psikologi Keluarga: Pemahaman Hakikat Keluarga dan Penanganan Problematika Rumah Tangga (J. Jamaludin \& Y. Sartika (eds.)). Ghalia Indonesia.

Weeks, F. H. (2000). Behaviour problems in the classroom: A model for teachers to assist learners with unmet emotional needs. Dissertation Abstracts International, 63(1-A), 89.http://ovidsp.ovid.com/ovidweb.cgi?T=JS\&CSC=Y\&NEWS=N\&PAGE=fullte $\mathrm{xt} \& \mathrm{D}=\mathrm{psyc} 4 \& \mathrm{AN}=2002-95013-$

060\%5Cnhttp://oxfordsfx.hosted.exlibrisgroup.com/oxford?sid=OVID:psycdb\&id =pmid: \&id=doi:\&issn=0419-4209\&isbn=\&volume=63\&issue $=1$ -

A\&spage $=89 \&$ pages $=89 \&$ date $=2002 \&$ title $=$ Di

Wiyani, N. A. (2012). Save our children from school bullying. Ar-Ruzz Media. 